Vol. 2, No. 2, 2019

\author{
I. P. Mertsalo, A. B. Bondarenko, A. S. Mazur, O. I. Kuntyi \\ Lviv Polytechnic National University, \\ Department of chemistry and technology of inorganic compounds \\ kunty@ukr.net
}

\title{
ANODE BEHAVIOR OF SILVER IN THE SOLUTION OF RHAMNOLIPID
}

https://doi.org/10.23939/ctas2019.02.007

Silver anodic dissolution in aqueous solutions of rhamnolipid (RL) has been investigated depending on the following parameters: concentration of RL, temperature, $\mathrm{pH}$ of medium and scanning speed of anode potential. It is shown that the active dissolution occurs at $\mathrm{E}>0.4 \mathrm{~V}$ in a wide range of concentrations of the surfactant at $t=20-50{ }^{\circ} \mathrm{C}$. With an increase in the concentration of rhamnolipid and temperature, the anode currents increase almost linearly with $\mathrm{E}=0.4-1.0 \mathrm{~V}$. They also increase with an increase in $\mathrm{pH}$ from 7 to 10 .

Keywords: silver, rhamnolipid, voltammetry, anodic dissolution, temperature coefficient, activation energy.

\section{Introduction}

Controlled synthesis of colloidal solutions of metal nanoparticles (MNPs) and, in particular, silver nanoparticles (AgNPs), in shape and size is one of the main tasks of metal nanochemistry [1-3]. The "green" synthesis of solutions of metallic nanoparticles is also problematic, including minimizing use of toxic substances as precursors $[4,5]$. One of the promising areas for solving such issues is electrochemical synthesis in solutions of non-toxic surfactants [6-11]. It allows you to regulate the formation of the geometry of nanoparticles and eliminates the need to use chemical reducing agents. Despite the widespread use for the stabilization of metals nanoparticles surfactants of natural origin [1-3, 12-15], studies on the possibility of their use in the electrochemical synthesis of MNPs are relevant.

\section{Analysis of recent research and publications}

Wide potential possibilities of silver nanoparticles (AgNPs) in catalysis, electronics, sensors, and especially in biomedicine determine an increased interest in such a nanomaterial $[1,2,6]$. The geometry and, accordingly, the properties of nanoparticles strongly depend on the methods of synthesis. Therefore, chemical and physicochemical processes associated with the formation of AgNPs are among the priority research directions of the last decade [1-3]. Much attention is also paid to "green" synthesis, based on minimizing toxic precursors - reducing agents and surfactant stabilizers. The most studied in the "green" synthesis is the chemical reduction of silver ions and the stabilization of AgNPs by organic substances of natural origin, especially plant extracts $[1,2,4,5]$. However, during chemical synthesis, the concentration of precursors changes, complicating the controlled formation of nanoparticles in shape and size. Therefore, as an alternative, electrochemical production of AgNPs [6-13] is promising, where the value of the electrode potential or current density is an effective factor in influencing the geometry of nanoparticles and their size distribution.

To ensure a constant concentration of silver ions in the reaction medium and to avoid contamination of the solutions with $\mathrm{NO}_{3}^{-}$anions, electrolysis is performed using soluble anodes [6-13]. The anode solubility depends on the nature of the surfactant; they act as stabilizers for AgNPs. However, the anodic behavior of silver in solutions of surfactants stabilizers has not been practically studied, which makes it difficult to control the concentration of $\mathrm{Ag}^{+}$ ions. In addition, the controlled provision of the active state of silver anodes becomes more complex, which leads to their passivation and the need to carry out electrolysis with variable polarity [8, 13]. Anodic dissolution of silver is also used to synthesize silver complexes with surfactant molecules as precursors of AgNPs [9]. Therefore, it is relevant to study the 


\section{P. Mertsalo, A. B. Bondarenko, A. S. Mazur, O. I. Kuntyi}

anodic behavior of silver in surfactant solutions of natural origin, in particular, rhamnolipid. The choice of such a stabilizer is due to its non-toxicity, availability and relatively low price $[14,15]$. Rhamnolipid are bio-surfactants whose molecules contain O-donor atoms (fig. 1). Due to donor-acceptor binding of the latter, they form complexes with metal ions [15-17].<smiles>CCC(CC(=O)O)OC(=O)CC(CC)OC1OC(C)[C@@H](O)C(O)[C@H]1O</smiles>

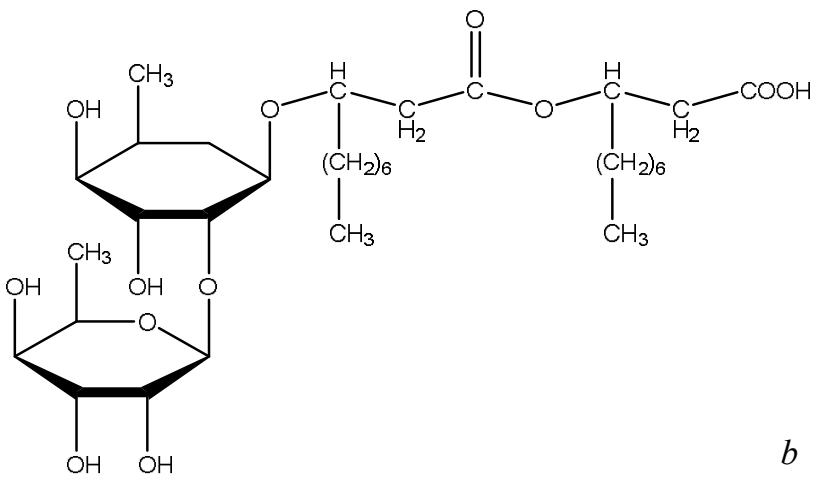

Fig. 1. Structural formula of mono-rhamnolipids (a) and di-rhamnolipids

Purpose of the research. The study of dependence of anodic silver dissolution speed in aqueous solutions of bio-surfactant - RL on such basic parameters of electrolysis: the concentration of surfactants, $\mathrm{pH}$ of the medium and temperatures and obtaining data that will be basic for the controlled electrochemical synthesis of colloidal solutions of stabilized silver nanoparticles.

\section{Materials and methods}

The method of studying the anode behavior of a silver electrode is voltammetry. The experiment was carried out in aqueous solutions of rhamnolipid with the following parameters: concentration, $\mathrm{C}(\mathrm{RL})=$ $=0.5-2,0 \mathrm{~g} \cdot \mathrm{L}^{-1} ; \mathrm{pH}=7-12$ (with the addition of $1 \mathrm{~N} \mathrm{NaOH}) \mathrm{t}=20-50{ }^{\circ} \mathrm{C}$; potential sweep speed, $v=20 \mathrm{mV} \cdot \mathrm{s}^{-1}$. The studies were conducted in a 50 $\mathrm{ml}$ electrochemical cell using three electrodes: a working silver electrode with an area of $0.2 \mathrm{~cm}^{2}$, a counter platinum electrode with an area of $05 \mathrm{~cm}^{2}$ and $\mathrm{Ag} / \mathrm{AgCl}$ as a reference electrode. The working electrode was polarized within E from $0.4-0.6$ to
1,0 V. Polarization curves were obtained using a PI-50-1 potentiostat, the PR-8 programmer. With the help of an analog-digital converter and a computer, the dependence of current on potential (I-E) was recorded.

\section{Results and discussion}

Taking into account the electrical donor properties of rhamnolipid molecules and, accordingly, the formation of soluble complexes with silver cations $[\mathrm{AgRL}]^{+}$, the processes on the surface of the silver anode and near-anode at $\mathrm{pH}=7$ can be represented by the following basic equations of electrochemical and chemical reactions:
$(+) \mathrm{Ag} \rightarrow \mathrm{Ag}_{\text {ads }}^{+}+\mathrm{e}$
$(+) \mathrm{Ag}_{\text {ads }}^{+}+\mathrm{RL} \rightarrow[\mathrm{AgRL}]_{\text {ads }}^{+}$
$(+) \mathrm{Ag}_{\text {ads }}^{+}+\mathrm{OH}^{-} \rightarrow \mathrm{AgOH}_{\text {ads }}$
$(+)[\mathrm{AgRL}]_{\text {ads }}^{+} \rightarrow[\mathrm{AgRL}]_{\text {solution }}^{+}$
(+) $\mathrm{AgOH}_{\mathrm{ads}}+\mathrm{RL} \rightarrow[\mathrm{AgRL}]_{\text {solution }}^{+}+\mathrm{OH}^{-}$

According to the above equations, the rate of anodic dissolution of silver (the $i_{\text {anode }}$ value) over smaller potentials of the oxygen electrolysis $(<1,0-1,1 \mathrm{~V})$ will depend primarily on the following parameters: 1) RL concentration $(2,3 \mathrm{a}) ; 2) \mathrm{pH}$ of the solution $(2 a), 3)$ temperatures (1-3a). The value of $\mathrm{i}_{\text {anode }}$ depends on the sweep rate of the anode potential $(v)$, which is due to the processes in the cathode layer during the course of reactions (2-3a). Therefore, the study of the dependence of the value of the $\mathrm{I}_{\text {anode }}$ on $\mathrm{C}(\mathrm{RL}), \mathrm{pH}$ and $\mathrm{t}$, was preceded by the choice of the value of $v$.

Characters of the E- $\mathrm{I}_{\text {anode }}$ curves in the range of the anodic potential sweep speed of $1-100 \mathrm{mV} \cdot \mathrm{s}^{-1}$ practically does not change (Fig. 2), which indicates the passage of identical electrode processes for different values of $v$.

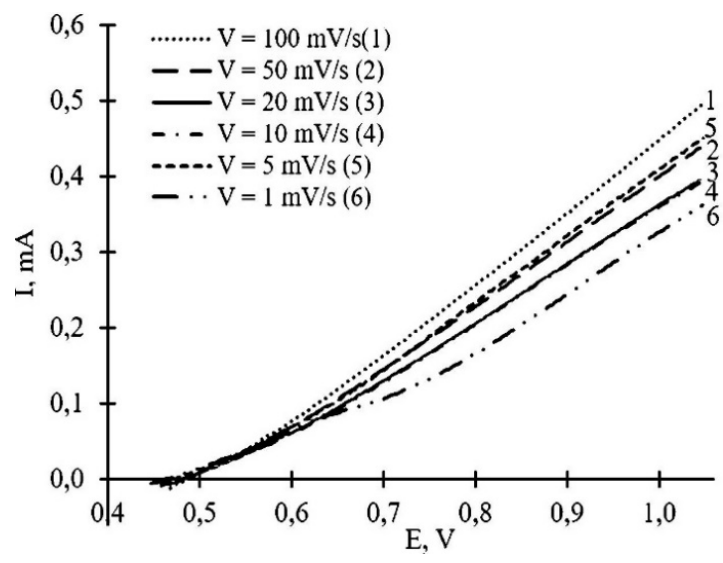

Fig. 2. Anodic polarization curves of silver in RL solution at different potential scanning speeds: $C=0.5 \mathrm{~g} \cdot \mathrm{L}^{-1} ; \mathrm{pH}=8 ; t=20^{\circ} \mathrm{C}$ 


\section{Anode behavior of silver in the solution of rhamnolipid}

Significant differences in the value of anode currents are observed in $v=1 \mathrm{mV} \cdot \mathrm{s}^{-1}$ and $v=$ $=100 \mathrm{mV} \cdot \mathrm{s}^{-1}$ (fig. 2 , curves 6 and 1 ). Such pattern is typical for anodic processes and is due to diffusion processes in the near-electrode layer. Despite the slight difference in the $\mathrm{I}_{\text {anode }}$ values for $v=5-50 \mathrm{mV} \cdot \mathrm{s}^{-1}$ and the fact that the anodic behavior in the literature is described mainly for $v=20 \mathrm{mV} \cdot \mathrm{s}^{-1}$, further studies were carried out at precisely this speed of anodic potential sweep.

With the increase in the concentration of the rhamnolipid, the anode currents, therefore, the current density and silver dissolution rate are increase (Fig. 3). This corresponds to equation (2), in which the rate of anodic dissolution of silver is proportional to the concentration of the surfactant.

Anodic polarization curves can be divided into two area: small (and) and high (II) currents. In a wide range of RL concentrations, the polarization curves in the second region $(\mathrm{E}>0.4 \mathrm{~V})$ are linear, therefore they correspond to active anodic dissolution of silver. However, the increase in anodic currents is not directly proportional to the increase in surfactant concentration, which is primarily due to diffusion restrictions - by bringing RL molecules to the double electric layer, their adsorption on the anode surface and desorption of the $[\mathrm{AgRL}]_{\mathrm{ads}}$ complexes with subsequent transportation to the electric double layer and volume of solution.

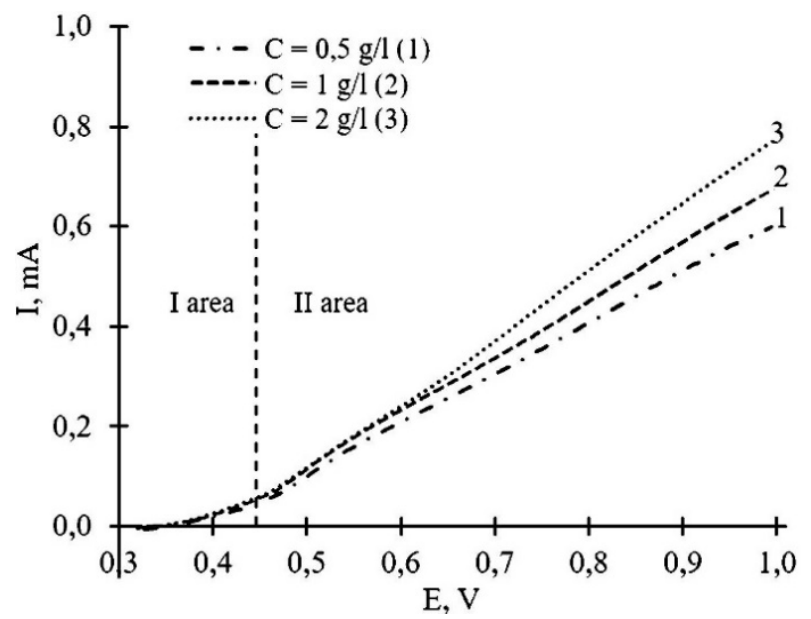

Fig. 3. Anodic polarization curves of silver in a solution of $R L$ depending on the surfactant concentration: $p H=8 ; t=20^{\circ} \mathrm{C}$

In the I area (Fig. 3), small values of anode currents were recorded, which can be explained by a significant overvoltage of anodic reaction caused by adsorption processes, primarily water molecules, $\mathrm{OH}$ anions, and the $[\mathrm{AgRL}]_{\mathrm{ads}}$ complex on the surface of a silver electrode. Increasing the level of $\mathrm{E}$, that is, the positive charge of the anode, contributes to the desorption of cations $[\mathrm{AgRL}]_{\mathrm{ads}}$ and polar $\mathrm{RL}$ molecules. As a consequence, the reaction rates increase $(2,3,3 a)$.

An increase in the $\mathrm{pH}$ value causes a significant increase in anodic currents without changing the nature of the polarization curves (Fig. 4). Such an increase in $\mathrm{I}_{\text {anode }}$ is due to an increase in the electrical conductivity of the solution and an increase in the flow rate of the parallel anodic reaction (2a). However, with an increase in the concentration of $\mathrm{OH}$ ions in solution, the anodic reaction (2a) may be predominant. This leads to the state of passive dissolution of the silver anode at $\mathrm{pH}=11$ and 12 (Fig. 4, curves 5 and 6), since the dissolution rate of $\mathrm{AgOH}_{\mathrm{ads}}$ with the formation of the $[\mathrm{AgRL}]^{+}$solution (3a) frame-lipid complex is slow for the reaction (2). According to the reaction (3a) becomes limiting. However, the rate of the latter depends on the concentration of the rhamnolipid. It was established that at $\mathrm{pH}=7-8$ only active anodic dissolution of silver is observed in the studied range of rhamnolipid concentrations.

With increasing temperature, there is a tendency to an increase in $\mathrm{I}_{\text {anode }}$ values (Fig. 5). However, there is no clear dependence of $I_{\text {anode }}-t$, apparently due to the simultaneous action of many factors, including the increase of electrical conductivity, the improvement of diffusion, the weakening of the adsorption of RL molecules on the anode surface.

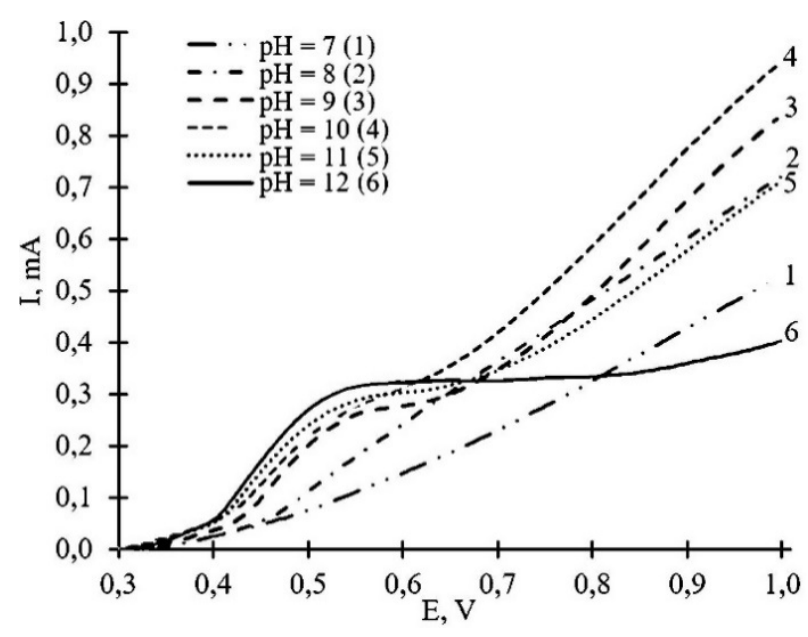

Fig. 4. Anodic polarization curves of silver in RL solution depending on $\mathrm{pH}$ values: $\mathrm{C}=1 \mathrm{~g} \cdot \mathrm{L}^{-1} ; t=20^{\circ} \mathrm{C}$ 


\section{P. Mertsalo, A. B. Bondarenko, A. S. Mazur, O. I. Kuntyi}

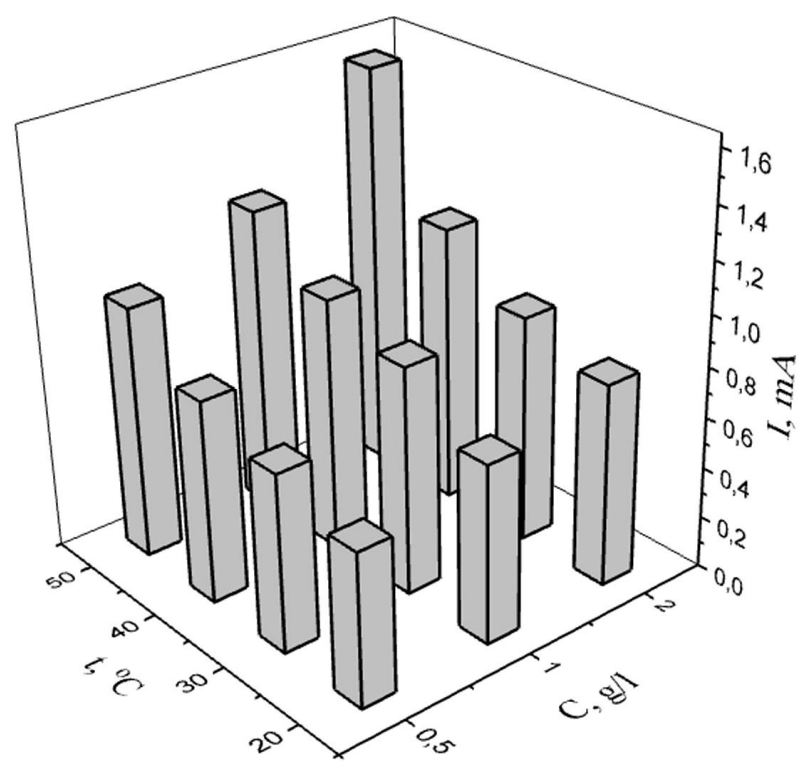

Fig. 5. The dependence of the magnitude of the anodic dissolution of silver on the concentration of rhamnolipid and temperature for $\mathrm{pH}=8, \mathrm{E}=1 \mathrm{~V}$

Calculated from the reduction polarization curves (Fig. 6), the activation energy of the electrochemical silver dissolution reaction in the temperature range of $20-50{ }^{\circ} \mathrm{C}$ and the concentrations studied are $13.4-24.7 \mathrm{~kJ} \cdot \mathrm{mol}^{-1}$.

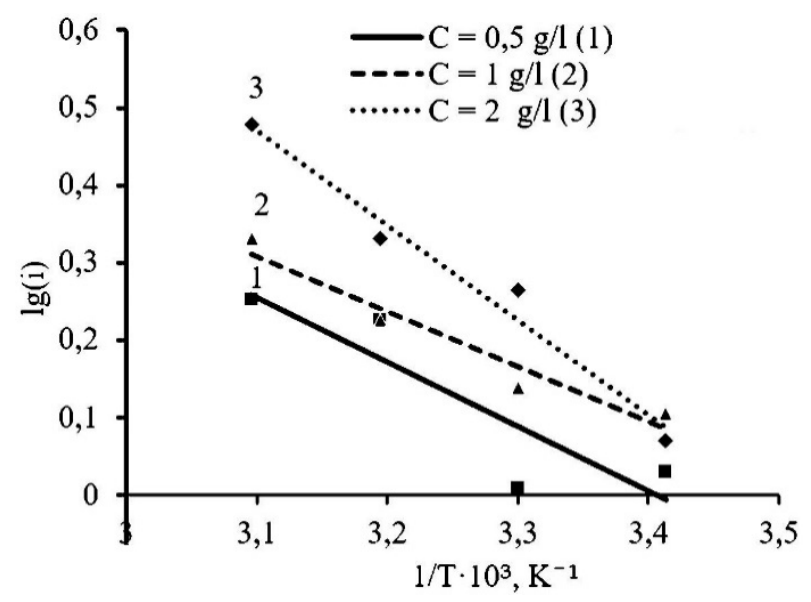

Fig. 6. The dependence of the logarithm of current density from $1 / T, E=+0.6 \mathrm{~V}, \mathrm{pH}=8, c_{r l}=0.5 \mathrm{~g} \cdot \mathrm{L}^{-1}, v=20 \mathrm{mV} \cdot \mathrm{s}^{-1}$

The temperature coefficient at the rhamnolipid concentration of $0.5-1,0 \mathrm{~g} \cdot \mathrm{L}^{-1}$ is $1.5-2.3 \% \cdot \mathrm{deg}^{-1}$, as the concentration increases to $2 \mathrm{~g} \cdot \mathrm{L}^{-1}$, the temperature coefficient rises to $5.6 \% \cdot \mathrm{deg}^{-1}$ The obtained results indicate that with an increase in temperature, the limiting stage of silver dissolution is the diffusion of reagents from the solution onto the surface of the anode and the reaction products in the opposite direction. The growth of the temperature coefficient is also due to adsorption processes.
So, the main parameters that affect the rate of anodic dissolution of silver in solutions of a rhamnolipid are the temperature and concentration of surfactants (Fig. 5).

In the range of the rhamnolipid concentration of $0.5-2,0 \mathrm{~g} \cdot \mathrm{L}^{-1}$ and temperatures of $20-50{ }^{\circ} \mathrm{C}$, high densities of anodic currents are provided (table), which corresponds to the technological rates of synthesis of the rhamnolipids complex of silver.

\section{Table}

\section{The value of anodic densities \\ of silver dissolution currents in solutions of rhamnolipid at $\mathrm{pH}=8, \mathrm{E}=1 \mathrm{~V}$}

\begin{tabular}{|c|c|c|c|}
\hline $\mathrm{t},{ }^{\circ} \mathrm{C} \quad \mathrm{C}, \mathrm{g} \cdot \mathrm{L}^{-1}$ & 0.5 & 1,0 & 2,0 \\
\hline 20 & 0.31 & 0.37 & 0.44 \\
\hline 30 & 0.28 & 0.47 & 0.48 \\
\hline 40 & 0.38 & 0.62 & 0.54 \\
\hline 50 & 0.51 & 0.72 & 0.84 \\
\hline
\end{tabular}

\section{Conclusions}

1. In an aqueous solution of rhamnolipid, active dissolution of silver occurs beyond the potentials E from $0.4-0.6 \mathrm{~V}$ to $1 \mathrm{~V}$ with a practically linear voltammper dependence. Moreover, soluble $[\mathrm{AgRL}]^{+}$is formed.

2. With an increase in the concentration of rhamnolipid and an increase in temperature, the anodic currents are grows and, accordingly, the silver dissolution rate.

3 . The activation energy of the electrochemical reaction is $13,4-24,7 \mathrm{~kJ} \cdot \mathrm{mol}^{-1}$, which indicates the diffusion component of the anodic dissolution currents. The value of the temperature coefficient at the concentration of rhamnolipid $0.5-1.0 \mathrm{~g} \cdot \mathrm{L}^{-1}$ equal to $1.5-2.3 \% \cdot \mathrm{deg}^{-1}$ confirms the diffusion of dissolution currents, and for increasing the concentration to $2 \mathrm{~g} \cdot \mathrm{L}^{-1}$ it grows and is $5.6 \% \cdot \mathrm{deg}^{-1}$, which indicates the presence of absorption currents.

4. In the range of the rhamnolipid concentration of $0.5-2.0 \mathrm{~g} \cdot \mathrm{L}^{-1}$ and temperatures of $20-50{ }^{\circ} \mathrm{C}$, high densities of anodic currents are provided (table), which corresponds to the technological rates of synthesis of the silver complexes.

\section{References}

1. Syafiuddin, A., Salmiati, Salim, M. R., Kueh, A. B., Hadibarata, T., \& Nur, H. (2017). A Review of Silver 
Nanoparticles: Research Trends, Global Consumption, Synthesis, Properties, and Future Challenges. Journal of the Chinese Chemical Society, 64(7), 732-756.

2. García-Barrasa, J., López-De-Luzuriaga, J., \& Monge, M. (2011). Silver nanoparticles: Synthesis through chemical methods in solution and biomedical applications. Open Chemistry, 9(1), 7-19

3. Kytsya, A., Bazylyak, L., Hrynda, Y., Horechyy, A., \& Medvedevdkikh, Y. (2015). The Kinetic Rate Law for the Autocatalytic Growth of Citrate-Stabilized Silver Nanoparticles. International Journal of Chemical Kinetics, 47(6), 351-360.

4. Srikar, S. K., Giri, D. D., Pal, D. B., Mishra, P. K. \& Upadhyay, S. N. (2016). Green Synthesis of Silver Nanoparticles: A Review. Green and Sustainable Chemistry, 6, 34-56.

5. Kumar, N., Salar, R. K., Kumar, R., Prasad, M., Brar, B. \& Nain, V. (2018). Green Synthesis of Silver Nanoparticles and its Applications - A Review. Journal of Nanotechnology and Applications, 19, 1-22.

6. Rodríguez-Sánchez, L., Blanco, M. C., \& LópezQuintela, M. A. (2000). Electrochemical Synthesis of Silver Nanoparticles. The Journal of Physical Chemistry $B, 104(41), 9683-9688$.

7. Starowicz, M., Stypuła, B., \& Banaś, J. (2006). Electrochemical synthesis of silver nanoparticles. Electrochemistry Communications, 8(2), 227-230.

8. Khaydarov, R. A., Khaydarov, R. R., Gapurova, O., Estrin, Y., \& Scheper, T. (2008). Electrochemical method for the synthesis of silver nanoparticles. Journal of Nanoparticle Research, 11(5), 1193-1200.

9. Reicha, F. M., Sarhan, A., Abdel-Hamid, M. I., \& El-Sherbiny, I. M. (2012). Preparation of silver nanoparticles in the presence of chitosan by electrochemical method. Carbohydrate Polymers, 89(1), 236-244.
10. Anicai, L., Dobre, N., Petica, A., Buda, M. \& Visan, T. (2014). Electrochemical synthesis of silver nanoparticles in aqueous electrolytes. UPB Scientific Bulletin, Series B: Chemistry and Materials Science, 76, 127-136.

11. Thuc, D. T., Huy, T. Q., Hoang, L. H., Tien, B. C., Chung, P. V., Thuy, N. T., \& Le, A. (2016). Green synthesis of colloidal silver nanoparticles through electrochemical method and their antibacterial activity. Materials Letters, 181, 173-177.

12. Nasretdinova, G. R., Fazleeva, R. R., Mikhitova, R. K., Nizameev, I. R., Kadirov M. K., Ziganshina, A. Y. \& Yanilkin, V. V. (2015). Electrochemical synthesis of silver nanoparticles in solution. Electrochemistry Communications, 50, 69-72.

13. Kuntyi, O. I., Kytsya A. R., Mertsalo I. P., Mazur A. S., Zozula G. I., Bazylyak L. I., Topchak R. V. (2019). Electrochemical synthesis of silver nanoparticles by reversible current in solutions of sodium polyacrylate. Colloid Polymer Science, 298, 1-7.

14. Varjani, S. J., \& Upasani, V. N. (2017). Critical review on biosurfactant analysis, purification and characterization using rhamnolipid as a model biosurfactant. Bioresource Technology, 232,389-397.

15. Stacey S. P., Mclaughlin M. J., Çakmak I., Hettiarachchi G. M., Scheckel K.G., Karkkainen M. (2008). Root uptake of lipophilic zinc-rhamnolipid complexes. Journal of Agricultural and Food Chemistry, 56, 2112-2117.

16. Hogan, D. E., Curry, J. E., Pemberton, J. E., \& Maier, R. M. (2017). Rhamnolipid biosurfactant complexation of rare earth elements. Journal of Hazardous Materials, 340, 171-178.

17. Kornii S. A., Pokhmurs'kyi V. I., Kopylets V. I., Zin I. M., Chervins'ka N. R. (2017) Quantum-chemical analysis of the electronic structures of inhibiting complexes of rhamnolipid with metals. Journal of Materials Science, 52(5), 609-619.

\section{І. П. Мерцало, А. Б. Бондаренко, А. С. Мазур, О. І. Кунтий \\ Національний університет “Львівська політехніка", кафедра хімії і технології неорганічних речовин}

\section{АНОДНА ПОВЕДІНКА СРІБЛА У РОЗЧИНАХ РАМНОЛІПДУ}

Досліджено анодне розчинення срібла у водних розчинах рамноліпіду (RL) залежно від таких параметрів: концентрації RL, температури, pH середовища та швидкості розгортки анодного потенціалу. Показано, що активне розчинення відбувається за Е $>0,4$ В у широкому діапазоні концентрацій поверхнево-активної речовини $3 \mathrm{a}=20-50{ }^{\circ} \mathrm{C}$. 3 підвищенням концентрації RL температури анодні струми зростають практично лінійно за $\mathrm{E}=\mathbf{0 , 4 - 1 , 0} \mathrm{B}$. Вони також зростають 33 підвищенням значення рН від 7 до 10.

Ключові слова: срібло, рамноліпід, вольтамперометрія, анодне розчинення, температурний коефіціснт, енергія активації. 